\section{Adequacy of prenatal care considering \\ Adequacy of prenatal care considering
nutritional assistance in Southern Brazil: Maternar Cohort Study}

\author{
Adequação de cuidados pré-natais e assistência \\ nutricional no Sul do Brasil: o Estudo de Coorte \\ Maternar
}

\section{Adecuación del cuidado prenatal considerando la asistencia nutricional en el sur de Brasil: Estudio de Cohorte Maternar}

\author{
Bruna Luiza Holand 1,2 \\ Simone Guerra Fonseca 1 \\ Michele Drehmer 1,2 \\ Vera Lúcia Bosa 1
}

\begin{abstract}
We verified the prevalence of adequacy in prenatal care considering nutritional assistance and associated factors. It is a cross-sectional study, part of Maternar Cohort Study, conducted between 2018-2019 in Southern Brazil. Women were interviewed during hospitalization in the immediate postpartum period and data were collected from the prenatal chart. Prenatal adequacy and nutritional care were assessed according to criteria from the Brazilian Ministry of Health. Two outcome models were constructed. Outcome 1 consisted of minimal coverage (early prenatal start and minimum number of visits) and exams, and Outcome 2 comprised minimal coverage, exams, and nutritional assistance. Poisson regression was used to estimate prevalence ratios. A total of 802 women were analyzed, and we identified 57\% of adequacy of Outcome 1. Unplanned pregnancy $(P R=0.76 ; 95 \% C I: 0.68-0.86)$, parity $(P R=0.88$; 95\%CI: 0.83-0.94) and prenatal care outside Porto Alegre, Rio Grande do Sul State (PR $=0.80 ; 95 \%$ CI: 0.69-0.92), were associated with lower prenatal adequacy frequencies. Outcome 2 was considered adequate for $10.2 \%$ of women. Follow-up by different professionals during prenatal care was associated with lower adequacy $(P R=0.49$; 95\%CI: 0.28-0.86). Women with high-risk pregnancies had a higher frequency of adequacy in Outcome $1(P R=1.21$; 95\%CI: 1.07-1.37) and in Outcome $2(P R=1.75$; 95\%CI: 1.16-2.64). General adequacy was considered low in both outcomes. There was a lack of nutritional assistance during prenatal care. Characteristics such as pregnancy planning, lower parity, prenatal care in Porto Alegre, follow-up by the same professional and high-risk pregnancy were predictors for the adequacy of prenatal care.
\end{abstract}

\author{
Correspondence \\ B. L. Holand \\ Departamento de Nutrição, Faculdade de Medicina, \\ Universidade Federal do Rio Grande do Sul. \\ Rua Ramiro Barcelos 2400, Porto Alegre, RS 90035-003, Brasil. \\ brunalholand@gmail.com \\ 1 Programa de Pós-graduação em Alimentação, \\ Nutrição e Saúde, Universidade Federal do Rio Grande do Sul, \\ Porto Alegre, Brasil. \\ 2 Programa de Pós-graduação em Epidemiologia, \\ Universidade Federal do Rio Grande do Sul, \\ Porto Alegre, Brasil.
}




\section{Introduction}

Prenatal care is a strong predictor for obstetric outcomes and impacts on maternal and fetal health. Its goal is to prevent gestational risk factors, as well as enable early diagnosis and treatment of obstetric complications 1,2 .

In Brazil, the persistence of inadequate health indicators, such as maternal mortality rate 3 , has supported public policies and health actions ${ }^{1}$. One of these policies is the Rede Cegonha strategy (Stork Network strategy) 2, created by the Brazilian Ministry of Health through the Humanization of Prenatal and Childbirth Care Program, which recommends an early start of prenatal care (before 12th week of pregnancy) in primary care, minimum of six visits, performed by physicians and nurses, complementary exams (hematocrit, fasting blood glucose, urine (type I and culture), serology for syphilis, hepatitis B, HIV and toxoplasmosis), promotion and encouragement of breastfeeding, as well as monitoring food intake and nutritional status of pregnant women attended by the Brazilian Unified National Health System (SUS) through the Brazilian Food and Nutritional Surveillance System (SISVAN).

The coverage of prenatal care has been expanding in Brazil and is close to universal (97.4\%; 95\%CI: 96.5-98.5) 1,4, however, this access does not necessarily mean adequacy. Difficulties to have an early beginning of care, as well as to accomplish the minimum number of visits and recommended complementary exams have been widely reported as the main reasons for inadequate prenatal care 5,6. Studies demonstrated variations in the frequency of adequacy due to the different criteria and levels of complexity used for the assessment. These evidences are consistent in the description that only a small portion of pregnant women received all the procedures recommended by the Ministry of Health during prenatal care $7,8,9$. Several factors are predictors of prenatal care adequacy. Higher maternal age, white skin color, higher income and education, presence of gestational risk factors such as type 2 diabetes mellitus or gestational diabetes, hypertension and other chronic diseases have been extensively associated with better adequacy care rates $8,9,10$. However, higher number of previous pregnancies, unplanned pregnancies, and feelings of dissatisfaction with the pregnancy have been related to lower frequencies of prenatal adequacy 9,11,12.

Regarding nutritional assistance during prenatal care, studies evaluating this component are scarce. Few studies that evaluated these relations did not consider the integrality of care and observed lack of nutritional assistance during pregnancy, making it difficult to diagnose risk factors, as well as performing interventions in a timely manner $13,14,15,16$. Indeed, it is well-established that gestational weight gain and maternal nutritional status have a major influence on gestational and perinatal outcomes 17,18 .

Considering the importance of integrated prenatal care to improve health and reduce maternal and child mortality rates, and that in general prenatal care adequacy is assessed through early beginning of care, number of visits and accomplishment of complementary exams, this study seeks to verify the prenatal care adequacy prevalence, in addition to considering nutritional assistance and its associated factors.

\section{Methods}

This is a cross-sectional study, as part of Maternar Cohort Study, which enrolled mothers at the maternity of a tertiary hospital in Porto Alegre, capital of the state of Rio Grande do Sul, Brazil, in the immediate postpartum period and followed them up to the child's sixth month of life.

\section{Population and sample}

The population was composed of puerperal women that were hospitalized to monitor the delivery and immediate postpartum period (12-48 hours after birth) at the maternity of Porto Alegre Hospital of Clinics (HCPA). The HCPA is a university hospital of national and international reference, certified by the Joint Commission International accreditation. Its maternity performs approximately 
3,500 births per year, mostly by SUS (96.4\%) and it is characterized for offering high complex care for mothers and children.

Inclusion criteria were: age greater than or equal to 19 years with multiple or single gestation, delivery of a live newborn or delivery of a stillborn fetus weighing more than $500 \mathrm{~g}$ and/or gestational age (GA) greater than 20 weeks, multiple or single gestation. We did not include in the study women who had prenatal care in a state other than Rio Grande do Sul, as well as those with psychological or mental impairment which did not allow communication with the researcher and with cognitive disability to answer the questionnaire.

The sample size calculation for this study seeks to meet the objective of identifying the prevalence of adequacy of prenatal care. The following parameters were used: $95 \%$ confidence level, $5 \%$ standard error and proportion of $21.6 \%$ of prenatal care adequacy in Brazil, according to data from a national representative study 8 carried out with 23,894 pregnant women in Brazil. The result of the sample size calculation obtained was 261 individuals. In order to contemplate possible losses, up to $20 \%$, the minimum sample size was set at 326 postpartum women. A sample of 400 individuals will produce a confidence interval up to 0.10 , if the observed proportion of adequacy is close to or less than 0.3 .

\section{Data collection}

Data collection was carried out by previously trained interviewers (nutritionists as well as nutrition and medical students) from April 2018 to September 2019. Sample selection occurred in a simple random way without replacement. Every day, all women considered eligible were sequentially coded and allocated vertically in a Excel spreadsheet (https://products.office.com/), and five mothers were randomly selected for the interview, considering the enrollment capacity of study.

Firstly, we reviewed the subject's electronic medical record, then an interview was conducted in person during hospitalization in the postpartum period, using a pre-structured questionnaire. Through the interview we obtained information such as maternal age, skin color/race, number of pregnancies, educational level, health-related habits, prenatal care, type of delivery. We also asked to photograph their prenatal chart to check for procedures and exams performed, pre-gestational and gestational anthropometric data and data on the newborn. The questionnaire was adapted from the instrument used in the study Birth in Brazil (Sergio Arouca National School of Public Health, Oswaldo Cruz Foundation. http://www6.ensp.fiocruz.br/nascerbrasil/questionarios-eletronicos/, accessed on $13 / \mathrm{Mar} / 2020$ ) and previously tested in a pilot study.

\section{Explanatory variables}

Some of the collected data were maternal age (calculated from the date of birth contained in the medical record), number of residents in the household living on monthly family income, monthly family income per capita with values in minimum wages (divided into terciles), educational level in complete years of study and parity as the number of previous births. Categorical explanatory variables were self-reported skin color (white/non-white - black, brown, yellow or indigenous), receiving the Brazilian Conditional Cash Transfer Program (Bolsa Família) (yes/no), paid maternal work (yes/no), marital status (married/stable union/live with partner/single). High-risk pregnancies - when there were complications or situations that characterize it, according to the criteria of Ministry of Health 2 (yes/no). Pre-gestational nutritional status was obtained through the pre-gestational body mass index (BMI) 19 , calculated from the pre-gestational weight and height recorded in the prenatal chart, when not available, the one referred by the puerperal woman was used $(<18.5 ; 18.5-24.9 ; 25-29.9 ; \geq 30 \mathrm{~kg} /$ $\mathrm{m}^{2}$ ). Pregnancy planning (yes/ no). We considered "planned pregnancy" when there was a planning report without the use of contraceptive methods at the beginning of pregnancy. Prenatal care attention performed by the same professional (yes/no), type of prenatal (public/private) and prenatal care in Porto Alegre (yes/no).

GA at delivery was calculated according to the first ultrasound when it occurred before the 20th week of pregnancy (88.8\%). If performed after 20 weeks, the time difference between the date of the last menstrual period and ultrasound was verified. When the difference was less than or equal to one 
week, ultrasound was used to calculate the GA. When the first ultrasound was performed after 30 weeks (2.1\%), the last menstrual period was used.

\section{Outcomes}

Prenatal care adequacy was assessed based on the valid criteria by Ministry of Health 2. Nutritional assistance is recommended during all visits and should be considered as part of adequacy. Therefore, a set of procedures was developed that characterize prenatal care adequacy, which were distributed in two models of complementary outcomes and of increasing complexity, as follows:

- Outcome 1 - Minimum coverage and exams: beginning of prenatal care at least at 12 weeks of pregnancy; compliance with the minimum number of prenatal visits for GA at delivery (one visit in the first trimester, two visits in the second trimester of pregnancy and three visits in the third trimester); at least one result recorded from each of the complementary exams recommended in the attention: ultrasound, hematocrit, fasting blood glucose, urine (type I and culture), serology for syphilis, hepatitis B, HIV and toxoplasmosis;

- Outcome 2 - Minimum coverage, exams (Outcome 1) + nutritional assistance: all procedures included in Outcome 1, adding the measurement of gestational weight during visits (0.7-1.0 ratio between measurement and number of visits was considered adequate); record in the prenatal chart of the pre-gestational weight and height; nutritional counseling according to " 10 steps for healthy eating for pregnant women" 2: (1) Intake of at least three meals and two snacks a day; (2) Intake of cereals and tubers at meals and preference to fresh foods; (3) Daily consumption of fruits and vegetables; (4) Daily intake of rice and beans; (5) Daily consumption of milk and dairy products, meat, poultry, fish or eggs; (6) Reduce the consumption of fats; (7) Avoid soft drinks and industrialized juices, as well as stuffed cookies and other treats on a daily basis; (8) Reduce the amount of salt in the food; (9) Daily intake of iron sources (offal, beans, lentils); (10) Gestational weight gain within the recommendations.

Nutritional counseling was identified through a previously structured questionnaire. For each of the 10 steps the question was asked (example for step 1): "During the prenatal visits, were you advised on intake of at least three meals and two snacks a day?" (Yes/No); and so on. This parameter was considered satisfactory when the ratio between the orientation received and recommended in the "10 steps for healthy eating for pregnant women" was greater than or equal to 0.7.

\section{Statistical analysis}

Descriptive analysis was performed by calculating the distribution of their frequencies, absolute and relative, with respective $95 \%$ confidence intervals $(95 \% \mathrm{CI})$ by calculating the mean and standard deviation. A multivariate analysis based on a theoretical model previously defined was elaborated in order to explain the outcomes 11,20. Our model includes three levels: distal, intermediate, and proximal (Figure 1). The analysis of factors associated with prenatal care adequacy, considering nutritional assistance, was performed by using Poisson regression with robust variance. Initially, a model was performed including variables of the distal level (socioeconomic and demographic characteristics). Those with $\mathrm{p}<0.20$ were included in the analysis of the following levels as covariates. The same occurred for the variables of the intermediate level (family characteristics and maternal health). Finally, maintaining the covariables of the first two levels, the variables of the proximal level (pregnancy planning and care characteristics) were included, composing the final multivariate theoretical model. Crude and adjusted prevalence ratios (PR) and their respective 95\%CI were estimated. Analyses were considered statistically significant when $\mathrm{p}<0.05$. For the analyses, women who did not carry out any prenatal visit and those who did not present the prenatal chart during the interview were excluded.

\section{Ethical considerations}

Participation in the study was voluntary and all subjects provided written informed consent. The study followed the criteria of Resolution n. 466/2012 of the Brazilian National Health Council, being approved by the HCPA Research Ethics Committee (n. 83872018.9.0000.5327). 


\section{Figure 1}

Theoretical model for prenatal care adequacy considering nutritional assistance. Maternar Cohort Study, Porto Alegre, Rio Grande do Sul State, Brazil, 2019.

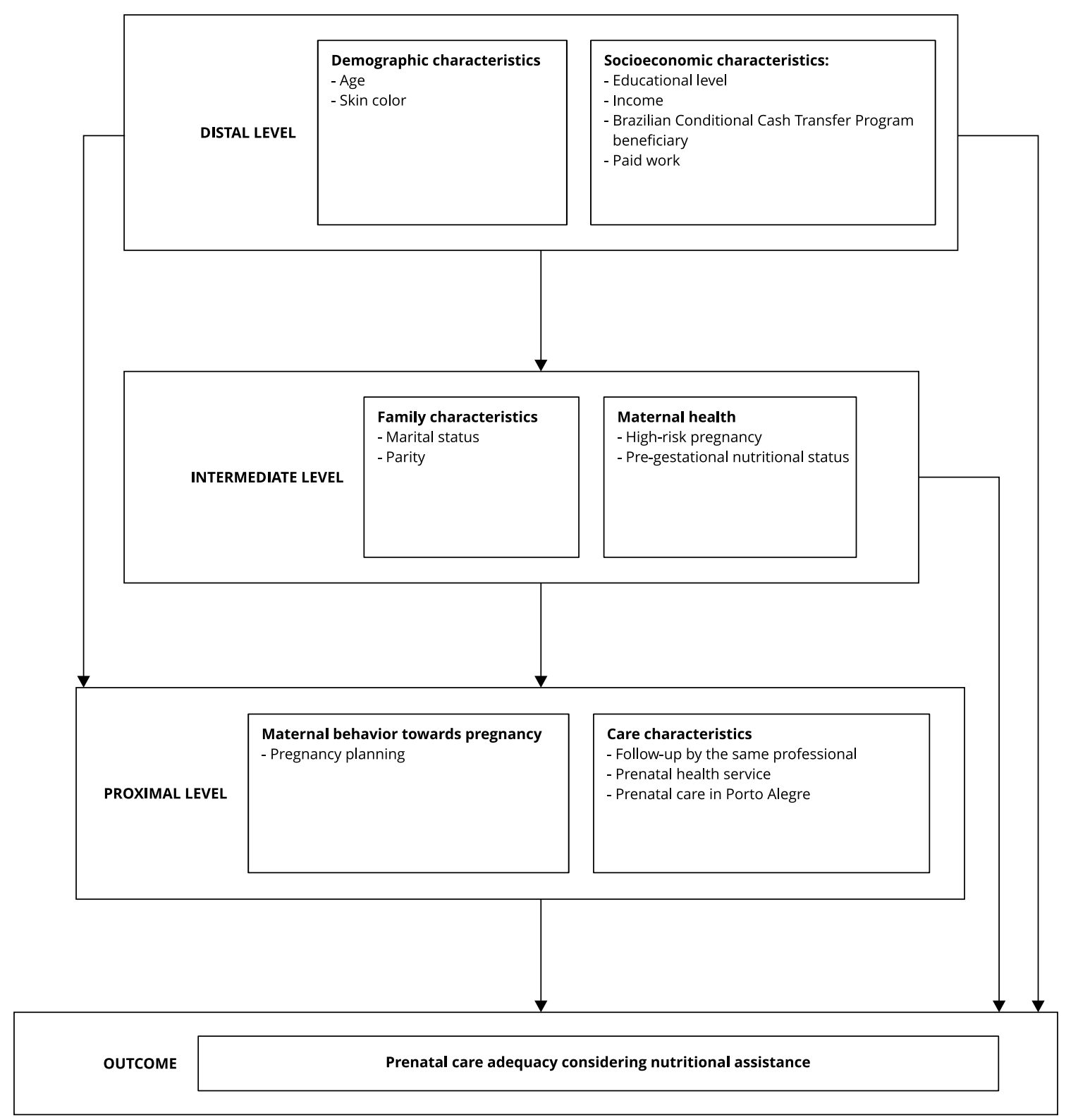

\section{Results}

From the 868 puerperal women who were interviewed by the study, $10(1.2 \%)$ were excluded from the analysis because they did not perform prenatal care and 56 (6.4\%) were excluded because they did not present the prenatal chart at the time of the interview. Therefore, 802 puerperal women were analyzed.

Table 1 shows the demographic, socioeconomic and obstetric characteristics of the puerperal women included in the study. The mean age was $28.8 \pm 6.1$ years, $55.2 \%$ declared themselves as white, $82.9 \%$ reported that they lived with a partner, $58.3 \%$ had previous pregnancies, $66.2 \%$ did not plan 
Table 1

Demographic, socioeconomic, obstetric, and prenatal care characteristics. Maternar Cohort Study, Porto Alegre, Rio Grande do Sul State, Brazil, 2019 ( $n=802)$.

\begin{tabular}{|c|c|}
\hline Characteristics & n (\%) \\
\hline \multicolumn{2}{|l|}{ Age (in years) } \\
\hline$\leq 24$ & $299(37.3)$ \\
\hline $25-34$ & $351(43.8)$ \\
\hline$\geq 35$ & $152(19.0)$ \\
\hline \multicolumn{2}{|l|}{ Skin color } \\
\hline White & $445(55.5)$ \\
\hline Non-white & $357(44.5)$ \\
\hline \multicolumn{2}{|l|}{ Education (in years) } \\
\hline$\leq 8$ & $233(29.1)$ \\
\hline $9-11$ & $416(51.9)$ \\
\hline$\geq 12$ & $153(19.1)$ \\
\hline \multicolumn{2}{|c|}{ Family income per capita (in terciles) * } \\
\hline $1 \mathrm{st}$ & $260(32.4)$ \\
\hline 2nd & $272(33.9)$ \\
\hline $3 r d$ & $270(33.7)$ \\
\hline \multicolumn{2}{|c|}{ Brazilian Conditional Cash Transfer Program beneficiary } \\
\hline Yes & $236(29.4)$ \\
\hline No & $566(70.6)$ \\
\hline \multicolumn{2}{|l|}{ Paid work } \\
\hline Yes & $392(48.9)$ \\
\hline No & $410(51.1)$ \\
\hline \multicolumn{2}{|l|}{ Marital status } \\
\hline With partner & $665(82.9)$ \\
\hline Without partner & $137(17.1)$ \\
\hline \multicolumn{2}{|l|}{ Parity } \\
\hline 0 & $335(41.8)$ \\
\hline $1-2$ & $375(46.8)$ \\
\hline$\geq 3$ & $92(11.5)$ \\
\hline \multicolumn{2}{|l|}{ High-risk pregnancy } \\
\hline Yes & $261(32.5)$ \\
\hline No & $541(67.5)$ \\
\hline \multicolumn{2}{|c|}{ Pre-gestational BMI $\left(\mathrm{kg} / \mathrm{m}^{2}\right) * *$} \\
\hline$<18.5$ & $19(2.5)$ \\
\hline $18.5-24.9$ & $323(42.4)$ \\
\hline $25-29.9$ & $242(31.8)$ \\
\hline$\geq 30$ & $177(23.3)$ \\
\hline \multicolumn{2}{|l|}{ Planned pregnancy } \\
\hline No & $531(66.2)$ \\
\hline Yes & $271(33.8)$ \\
\hline \multicolumn{2}{|c|}{ Pregnancy follow-up by the same professional } \\
\hline No & $180(22.4)$ \\
\hline Yes & $622(77.6)$ \\
\hline \multicolumn{2}{|c|}{ Prenatal care in Porto Alegre } \\
\hline Yes & $554(69.1)$ \\
\hline No & 248 (30.9) \\
\hline
\end{tabular}

(continues) 
Table 1 (continued)

\begin{tabular}{lc}
\hline Characteristics & $\mathbf{n}(\%)$ \\
\hline $\begin{array}{l}\text { Prenatal health service } \\
\quad \text { Public }\end{array}$ \\
$\quad$ Private & $650(81.0)$ \\
Number of visits & $152(19.0)$ \\
$\quad<6$ & \\
$\geq 6$ & $84(10.5)$ \\
Beginning of prenatal care (weeks) & $718(89.5)$ \\
$\leq 12$ & \\
$>12$ & $539(67.2)$ \\
Nutritional counseling & $263(32.8)$ \\
Yes & \\
No & $466(58.1)$ \\
\hline
\end{tabular}

BMI: body mass index.

* 1st tercile: USD 4.68-USD 70.29; 2nd tercile: USD 70.30-USD 120.49; 3rd tercile: USD 120.50-USD 703.18;

$\star \star n=761$.

their pregnancy, the average level of education was $9.7 \pm 2.1$ years, $32 \%$ of pregnant women were classified as high-risk, $81 \%$ performed prenatal care in the public sector and $69.1 \%$ in Porto Alegre. Minimum number of visits was performed by $89.5 \%$ (95\%CI: 87.4-91.6) of puerperal women, and early beginning of prenatal care was identified in 67.2\% (95\%CI: 63.9-70.4) of the sample. Nutritional counseling according to the " 10 steps to healthy eating for pregnant women" were reported by $58.1 \%$ (95\%CI: 54.6-61.5) of women. It should be noted that among puerperal women who were excluded mostly were non-white, with lower education, higher parity, lower frequency of pregnancy risk and planned pregnancy, as well as fewer visits during prenatal care (data not shown in the table).

We found a prevalence of $85 \%$ (95\%CI: 82.5-87.5) regarding to the record of at least one result of each of the complementary exams recommended during prenatal care. The record of pre-gestational weight and height were identified in 42.8\% (95\%CI: 39.3-46.2) and 34.8\% (95\%CI: 31.2-38.1), respectively, of prenatal chart. The frequency found for recording gestational weight in at least $70 \%$ of prenatal visits was of $84.9 \%$ (95\%CI: 82.4-87.3). Prenatal care adequacy according to Outcome 1 (minimum coverage and exams) was observed in 57\% of women (95\%CI: 53.5-60.4). For Outcome 2 (minimum coverage, exams and nutritional assistance), an adequacy of 10.2\% (95\%CI: 8.1-12.3) was observed (data not shown in the table).

Table 2 shows the crude and adjusted prevalence ratios according to the theoretical model. In the final multivariate model for Outcome 1 (minimum coverage and exams), after adjusting for income, marital status, gestational risk, parity and pre-gestational BMI, it was identified that unplanned pregnancies $(\mathrm{PR}=0.76$; 95\%CI: 0.68-0.86), higher parity $(\mathrm{PR}=0.88$; 95\%CI: 0.83-0.94) and performing prenatal care outside of the capital ( $P R=0.80$; 95\%CI: 0.69-0.92) were associated with lower adequacy when compared to women who planned their pregnancy, had fewer children and performed prenatal care in the capital of Rio Grande do Sul State. Higher frequency of adequacy was observed in women with high-risk pregnancies, in which $21 \%$ were more likely to have an adequate prenatal care then those with low risk ( $\mathrm{PR}=1.21 ; 95 \% \mathrm{CI}$ : $1.07-1.37)$.

Outcome 2 (minimum coverage, exams, and nutritional assistance) was adjusted for gestational risk, parity and pre-gestational BMI. Women with high-risk pregnancies are $75 \%$ more likely $(\mathrm{PR}=$ 1.75; 95\%CI: $1.16-2.64)$ to have an adequate prenatal care when compared to those with low-risk pregnancies. Women who had unplanned pregnancies and those who were followed up by different professionals during prenatal care presented, respectively, 46\% (PR = 0.54; 95\%CI: $0.36-0.83)$ and 52\% $(P R=0.48$; 95\%CI: 0.28-0.85) lower probability of adequacy, when compared to those who planned their pregnancy and were followed up during prenatal care by the same professional. 
Table 2

Crude and adjusted prevalence ratios by Poisson regression with robust variance according to the theoretical model between factors and Outcomes 1 (minimum coverage and exams) and 2 (minimum coverage, exams and nutritional assistance). Maternar Cohort Study, Porto Alegre, Rio Grande do Sul State, Brazil, 2019 ( $n=802)$.

\begin{tabular}{|c|c|c|c|c|}
\hline \multirow[t]{2}{*}{ Characteristics } & \multicolumn{2}{|c|}{ Outcome 1} & \multicolumn{2}{|c|}{ Outcome 2} \\
\hline & $\operatorname{PRc}(95 \% \mathrm{Cl})$ & $\operatorname{PRa}(95 \% \mathrm{Cl})$ & PRc $(95 \% \mathrm{Cl})$ & $\operatorname{PRa}(95 \% \mathrm{Cl})$ \\
\hline \multicolumn{5}{|l|}{ Distal level } \\
\hline Age & $1.00(0.99-1.01)$ & $1.00(0.99-1.01)$ & $0.99(0.96-1.03)$ & $0.99(0.96-1.03)$ \\
\hline Education & $1.00(0.97-1.02)$ & $0.98(0.95-1.01)$ & $1.04(0.94-1.16)$ & $1.02(0.91-1.13)$ \\
\hline \multicolumn{5}{|l|}{ Skin color } \\
\hline Non-white & $0.94(0.83-1.06)$ & $0.95(0.84-1.07)$ & $0.79(0.52-1.21)$ & $0.83(0.55-1.25)$ \\
\hline White & 1.00 & 1.00 & 1.00 & 1.00 \\
\hline \multicolumn{5}{|c|}{ Family income per capita (in terciles) * } \\
\hline $1 \mathrm{st}$ & $0.89(0.76-1.04)$ & $0.86(0.72-1.03)$ & $0.71(0.42-1.19)$ & $0.74(0.43-1.29)$ \\
\hline 2nd & $1.06(0.92-1.22)$ & $1.05(0.93-1.21)$ & $0.86(0.53-1.4)$ & $0.88(0.55-1.41)$ \\
\hline $3 r d$ & 1.00 & 1.00 & 1.00 & 1.00 \\
\hline \multicolumn{5}{|c|}{$\begin{array}{l}\text { Brazilian Conditional Cash Transfer Program } \\
\text { beneficiary }\end{array}$} \\
\hline Yes & $0.98(0.86-1.12)$ & $1.01(0.87-1.16)$ & $0.93(0.59-1.48)$ & $1.04(0.63-1.71)$ \\
\hline No & 1.00 & 1.00 & 1.00 & 1.00 \\
\hline \multicolumn{5}{|l|}{ Employment } \\
\hline No & $0.98(0.87-1.11)$ & $1.02(0.89-1.16)$ & $0.95(0.63-1.44)$ & $1.04(0.67-1.62)$ \\
\hline Yes & 1.00 & 1.00 & 1.00 & 1.00 \\
\hline \multicolumn{5}{|l|}{ Intermediate level } \\
\hline Parity & $0.89(0.84-0.95) * *$ & $0.88(0.83-0.94) * *$ & $0.98(0.81-1.19)$ & $0.93(0.77-1.14)$ \\
\hline Pre-gestational BMI & $1.00(0.99-1.01)$ & $1.00(1.00-1.01) * *$ & $1.03(0.99-1.06)$ & $1.02(0.99-1.05)$ \\
\hline \multicolumn{5}{|l|}{ Marital status } \\
\hline Without partner & $0.85(0.71-1.01)$ & $0.86(0.72-1.04)$ & $0.83(0.46-1.49)$ & $0.87(0.49-1.56)$ \\
\hline With partner & 1.00 & 1.00 & 1.00 & 1.00 \\
\hline \multicolumn{5}{|l|}{ High-risk pregnancy } \\
\hline Yes & $1.20(1.06-1.35) * *$ & $1.21(1.07-1.37) * *$ & $1.79(1.19-2.69) * *$ & $1.75(1.16-2.64)$ ** \\
\hline No & 1.00 & 1.00 & 1.00 & 1.00 \\
\hline \multicolumn{5}{|l|}{ Proximal level } \\
\hline \multicolumn{5}{|l|}{ Planned pregnancy } \\
\hline No & $0.73(0.65-0.82) * *$ & $0.76(0.68-0.86) * *$ & $0.51(0.34-0.76) * *$ & $0.54(0.36-0.83) * *$ \\
\hline Yes & 1.00 & 1.00 & 1.00 & 1.00 \\
\hline \multicolumn{5}{|c|}{ Pregnancy follow-up by the same professional } \\
\hline No & $0.94(0.81-1.09)$ & $0.89(0.76-1.04)$ & $0.59(0.32-1.06)$ & $0.48(0.28-0.85) * *$ \\
\hline Yes & 1.00 & 1.00 & 1.00 & 1.00 \\
\hline \multicolumn{5}{|c|}{ Prenatal care in Porto Alegre } \\
\hline No & $0.82(0.71-0.94) * *$ & $0.80(0.69-0.92)$ ** & $1.35(0.89-2.06)$ & $1.28(0.85-1.92)$ \\
\hline Yes & 1.00 & 1.00 & 1.00 & 1.00 \\
\hline \multicolumn{5}{|c|}{ Prenatal health service } \\
\hline Private & $0.90(0.77-1.07)$ & $0.87(0.74-1.03)$ & $1.03(0.61-1.73)$ & $1.01(0.60-1.70)$ \\
\hline Public & 1.00 & 1.00 & 1.00 & 1.00 \\
\hline
\end{tabular}

95\% Cl: 95\% confidence interval; BMI: body mass index; PRa: adjusted prevalence ratio; PRc: crude prevalence ratio.

Note: minimum coverage is equivalent to the beginning of prenatal care before the 12th week of pregnancy and the accomplishment of the minimum number of visits for gestational age.

Note: values in bold expressed p-value $<0.20$.

* 1st tercile: USD 4.68-USD 70.29; 2nd tercile: USD 70.30-USD 120.49; 3rd tercile: USD 120.50-USD 703.18;

** p-value $<0.05$ 


\section{Discussion}

This study sought to evaluate the prevalence of prenatal care adequacy considering nutritional assistance, as well as to identify associated factors. Regarding minimum coverage and exams, we identified an adequacy of $57 \%$, with higher frequencies of adequacy being associated with pre-gestational BMI and high-risk pregnancy. Unplanned pregnancies decreased adequacy by $24 \%$ and performing prenatal care outside of the capital decreased the probability of prenatal care adequacy by $20 \%$. Considering minimum coverage, exams and nutritional assistance, the frequency of adequacy found was of $10.2 \%$. The factors associated with the adequacy of the minimum coverage, exams and nutritional assistance were high-risk pregnancies, pregnancy planning and prenatal care followed up by the same professional.

The high coverage of prenatal care verified (98.8\%, data not shown) corroborates the findings of previous studies conducted with Brazilian pregnant women 4,11,21. However, access to assistance may not guarantee adequacy $7,8,9,10$. Over half of women received adequate prenatal care, considering minimum coverage and exams. Meantime, studies 7,8,9,10,11 that evaluated prenatal care in terms of early beginning of care, number of visits and complementary exams, obtained results whose frequency of adequacy varied between $21.6 \%$ and $39.8 \%$. Likewise, other national studies $8,10,21$ reveal that women who perform prenatal care in the South and Southeast regions are more likely to have approximately $20 \%$ higher adequacy than women from other Brazilian regions, revealing disparities. No relation was found between adequacy of minimum coverage and exams with age, skin color, income, and level of education, although unfavorable economic conditions have been widely associated with prenatal care inadequacy 8,9,20. In our study, the lack of association with skin color and education could be explained by the puerperal women who were excluded from the analysis, which presented non-white skin color and low level of education. These characteristics differed statistically from included women. Nevertheless, our findings corroborate with a cross-sectional study conducted in Porto Alegre 11, suggesting a prenatal care with better equity in the region, and provide consistency to our results. Another study conducted with data from the Brazilian National Health Survey conducted in 2013, did not identify an association between the adequacy of prenatal care with age and maternal education 10 .

We observed a dose-response association between parity and adequacy of minimum coverage and exams. Primiparity has been associated with better adequacy of prenatal care in several studies 8,9,11,22. It is believed that with the increase in the number of pregnancies, women consider themselves to have sufficient knowledge and experience with pregnancy to deal with it on their own 23 . Unplanned pregnancies were also related to lower adequacy of minimum coverage and exams, shown by similar results obtained in another study ${ }^{11}$. A plausible explanation for these results could be the fact that women with unplanned pregnancies or who feel dissatisfied with it are more likely to begin prenatal care later and perform fewer visits - for the late diagnosis of pregnancy and/or for not attending to the scheduled appointments 24,25 . Less probability of prenatal care adequacy was observed in women who did not perform prenatal care in the capital of Rio Grande do Sul State. On the other hand, a greater probability of performing adequate prenatal care with minimal coverage and examinations was observed in women with pregnancies characterized as high-risk. These results can be explained by referral to a high-risk pregnancy reference center in the capital.

Assessing the more complex model, which considers the minimum coverage, exams and nutritional assistance, adequacy was only of $10.2 \%$. Women with high-risk pregnancies showed a higher frequency of adequacy compared to those with low-risk pregnancies. Another factor associated with minimum coverage, exams, and nutritional assistance was the professional care received throughout pregnancy. Women who were assisted by different professionals had half the chances of having an adequate prenatal care when compared to those assisted by the same professional during pregnancy. Continuity of care is essential for creating a relationship of trust between the professional and the pregnant woman. It can guarantee a better adherence of women to prenatal care, as well as guidance and less fragmented procedures by professionals 26 . The non-mandatory presence of a professional dietitian in the Family Health Strategy, specialized and qualified to perform nutritional surveillance and education, may be contributing to a fragmented and incomplete prenatal care.

Record of pre-gestational weight and height, which are essential for diagnosis and nutritional assistance, are present respectively in $42.8 \%$ and $34.8 \%$ of prenatal booklets. These were lower values 
when compared to those found in a previous study 15. Gestational weight record in at least $70 \%$ of visits was considered adequate in most prenatal charts. Similar data were found previously, where the record of gestational weight was considered adequate for approximately $90 \%$ of women 8,15,27,28. However, we also questioned how effectively this procedure contributes to the adequacy of assistance, since weight alone is not capable of generating a diagnosis or nutritional monitoring 2,19 . We identified that $58.1 \%$ of women received at least seven among the 10 nutritional counseling recommended by the Brazilian Ministry of Health. This value was higher than in other studies that used similar counseling 15,16. A systematic review identified that although health professionals perceive the importance of nutritional counseling, they were not considered a priority in the care process 29 .

Recommended procedures in prenatal care with lower compliance rates, that contributed to lower frequencies of prenatal care adequacy, were early beginning of care, register of pre-gestational weight and height and nutritional counseling. The low rate of conformity of the procedures that characterize nutritional assistance in prenatal care is worrisome, considering that adequate nutritional assistance can prevent gestational and neonatal risk factors, such as gestational diabetes, gestational hypertensive syndromes, low birth weight, prematurity, and macrosomia 17,30.

As for the limitations of this study, it is worth mentioning the fact that it was performed only in the city of Porto Alegre, in a single tertiary hospital. Even though HCPA is a reference hospital for the city, the state of Rio Grande do Sul and other regions, the results found may be less able to be generalized to other populations. In addition, it was carried out with adult pregnant women, and should be carefully analyzed in populations with different age groups. Another issue that should be considered is the possible underreporting of the complementary and physical exams data in the prenatal chart. There is no guarantee that the failure to register the procedures would indicate that they have not been carried out. However, it still represents a failure in the process since it prevents an effective interprofessional communication.

In general, our findings are in line with the existing literature. The frequency of adequacy in both outcomes remains below the desired level, considering the importance of prenatal care for maternal and child health. Moreover, the fact that frequency of Outcome 2, which considers nutritional assistance, represents approximately one fifth of the adequacy of Outcome 1 (minimum coverage and exams), highlights the need for training and creating guidelines that value nutritional assistance procedures. Our study demonstrated that pregnancy planning, lower parity, performing prenatal care in the capital, follow-up by the same professional and high-risk pregnancies were predictors of prenatal care adequacy.

To the best of our knowledge this is a pioneering study, as it considers nutritional assistance in the prenatal care adequacy, as recommended by the Brazilian Ministry of Health. There is room for further studies on this matter, in order to expand the body of evidence on the integrated prenatal care. Our results identify the procedures that contribute to lower adequacy frequencies and the associated factors, as well as highlight the lack of nutritional assistance during this period, which may be related to the very low number of dietitians who work in primary care attention. This study provides subsidies to health managers in the form of epidemiological information, for the elaboration of strategic actions and programs that improve prenatal attention, minimize these inequities, and effectively benefit this population. 


\section{Contributors}

B. L. Holand conceived the idea, performed data collection, data analyses and interpretation, and wrote most of the paper. S. G. Fonseca performed data collection and provided revisions to scientific content and grammar of the manuscript. M. Drehmer conceived the idea, reviewed the data analysis and interpretation, co-wrote the paper and provided revisions to scientific content and grammar of the manuscript. V. L. Bosa conceived the idea, reviewed the data analysis and interpretation, co-wrote the paper and provided revisions to scientific content and grammar of the manuscript.

\section{Additional informations}

ORCID: Bruna Luiza Holand (0000-0003-39317622); Simone Guerra Fonseca (0000-0003-24115876); Michele Drehmer (0000-0002-5996-2672); Vera Lúcia Bosa (0000-0002-6283-9640).

\section{Acknowledgments}

To Research and Events Incentive Fund (FIPE), Porto Alegre Hospital of Clinics (HCPA).

\section{References}

1. Leal MC, Szwarcwald CL, Almeida PVB, Aquino EML, Barreto ML, Barros F, et al. Saúde reprodutiva, materna, neonatal e infantil nos 30 anos do Sistema Único de Saúde (SUS). Ciênc Saúde Colet 2018; 23:1915-28.

2. Departamento de Atenção Básica, Secretaria de Atenção à Saúde, Ministério da Saúde. Atenção ao pré-natal de baixo risco. Brasília: Ministério da Saúde; 2013.

3. Instituto Brasileiro de Geografia e Estatística. Indicadores brasileiros para os objetivos de desenvolvimento sustentável. https://odsbrasil. gov.br (accessed on 14/Dec/2019).

4. Instituto Brasileiro de Geografia e Estatística. Pesquisa Nacional de Saúde 2013. https://sidra. ibge.gov.br/tabela/5812 (accessed on 13/Dec/ 2019).

5. Andreucci CB, Cecatti JG. Desempenho de indicadores de processo do Programa de Humanização do Pré-Natal e Nascimento no Brasil: uma revisão sistemática. Cad Saúde Pública 2011; 27:1053-64.

6. Nunes JT, Oliveira KRG, Pacheco MTR, Medeiros MDM. Qualidade da assistência pré-natal no Brasil: revisão de artigos publicados de 2005 a 2015. Cad Saúde Colet (Rio J.) 2016; 24:252-61.

7. Polgliane RBS, Leal MC, Amorim MHC, Zandonade E, Santos Neto ET. Adequação do processo de assistência pré-natal segundo critérios do Programa de Humanização do Pré-natal e Nascimento e da Organização Mundial de Saúde. Ciênc Saúde Colet 2014; 19:1999-2010.

8. Domingues RMSM, Viellas EF, Dias MAB, Torres JA, Theme-Filha MM, Gama SGN, et al. Adequacy of prenatal care according to maternal characteristics in Brazil. Rev Panam Salud Pública 2015; 37:140-7.

9. Goudard MJF, Simões VMF, Batista RFL, Queiroz RCDS, Brito e Alves MTSS, Coimbra LC, et al. Inadequacy of the content of prenatal care and associated factors in a cohort in the northeast of Brazil. Ciênc Saúde Colet 2016; 21:1227-38.

10. Mario DN, Rigo L, Boclin KDLS, Malvestio LMM, Anziliero D, Horta BL, et al. Qualidade do pré-natal no Brasil: Pesquisa Nacional de Saúde 2013. Ciênc Saúde Colet 2019; 24:122332.

11. Bassani DG, Surkan PJ, Olinto MTA. Inadequate use of prenatal services among Brazilian women: the role of maternal characteristics. Int Perspect Sex Reprod Health 2009; 35:1520.

12. Silva EPD, Leite AFB, Lima RT, Osório MM. Avaliação do pré-natal na atenção primária no Nordeste do Brasil: fatores associados à sua adequação. Rev Saúde Pública 2019; 53:43.

13. Santos MMAS, Baião MR, Barros DC, Pinto AA, Pedrosa PLM, Saunders C. Estado nutricional pré-gestacional, ganho de peso materno, condições da assistência pré-natal e desfechos perinatais adversos entre puérperas adolescentes. Rev Bras Epidemiol 2012; 15:143-54. 
14. Laporte-Pinfildi ASC, Zangirolani LTO, Spina N, Martins PA, Medeiros MAT. The nutritional care during the prenatal and postpartum: perceptions of managers of primary health care. Rev Nutr 2016; 29:109-23.

15. Niquini RP, Bittencourt SA, Lacerda EMDA, Saunders C, Leal MC. Avaliação do processo da assistência nutricional no pré-natal em sete unidades de saúde da família do Município do Rio de Janeiro. Ciênc Saúde Colet 2012; 17:2805-16.

16. Lisboa CS, Bittencourt JL, Santana JM, Santos DB. Assistência nutricional no pré-natal de mulheres atendidas em unidades de saúde da família de um município do Recôncavo da Bahia: um estudo de coorte. Demetra (Rio J.) 2017; 12:713-31.

17. Goldstein RF, Abell SK, Ranasinha S, Misso ML, Boyle JA, Black MH, et al. Association of gestational weight gain with maternal and infant outcomes: a systematic review and metaanalysis. JAMA 2017; 317:2207-25.

18. Kominiarek MA, Saade G, Mele L, Bailit J, Reddy UM, Wapner RJ, et al. Association between gestational weight gain and perinatal outcomes. Obstet Gynecol 2018; 132:875-81.

19. Institute of Medicine; National Research Council. Weight gain during pregnancy: reexamining the guidelines. Washington DC: National Academies Press; 2009.

20. Victora CG, Huttly SR, Fuchs SC, Olinto MT. The role of conceptual frameworks in epidemiological analysis: a hierarchical approach. Int J Epidemiol 1997; 26:224-7.

21. Viellas EF, Domingues RMSM, Dias MAB, Gama SGN, Theme Filha MM, Costa JV, et al. Assistência pré-natal no Brasil. Cad Saúde Pública 2014; 30 Suppl:S85-100.

22. Trevisan MR, De-Lorenzi DRS, Araújo NM, Ésber K. Perfil da assistência pré-natal entre usuárias do Sistema Único de Saúde em Caxias do Sul. Rev Bras Ginecol Obstet 2002; 24:293-9.
23. Celik Y, Hotchkiss DR. The socio-economic determinants of maternal health care utilization in Turkey. Soc Sci Med 2000; 50:1797806.

24. Dibaba Y, Fantahun M, Hindin MJ. The effects of pregnancy intention on the use of antenatal care services: systematic review and metaanalysis. Reprod Health 2013; 10:50.

25. Bayou YT, Mashalla YS, Thupayagale-Tshweneagae $G$. The adequacy of antenatal care services among slum residents in Addis Ababa, Ethiopia. BMC Pregnancy Childbirth 2016; 16:142.

26. Petrou S, Kupek E, Vause S, Maresh M. Clinical, provider and sociodemographic determinants of the number of antenatal visits in England and Wales. Soc Sci Med 2001; 52:112334.

27. Parada CMGL. Avaliação da assistência prénatal e puerperal desenvolvidas em região do interior do Estado de São Paulo em 2005. Rev Bras Saúde Mater Infant 2008; 8:113-24.

28. Coutinho T, Monteiro MFG, Sayd JD, Teixeira MTB, Coutinho CM, Coutinho LM. Monitoramento do processo de assistência pré-natal entre as usuárias do Sistema Único de Saúde em município do Sudeste brasileiro. Rev Bras Ginecol Obstet 2010; 32:563-9.

29. Lucas C, Charlton KE, Yeatman H. Nutrition advice during pregnancy: do women receive it and can health professionals provide it? Matern Child Health J 2014; 18:2465-78.

30. Xiao L, Ding G, Vinturache A, Xu J, Ding Y, Guo J, et al. Associations of maternal pre-pregnancy body mass index and gestational weight gain with birth outcomes in Shanghai, China. Sci Rep 2017; 7:41073. 


\section{Resumo}

Verificamos a prevalência de adequação da atenção pré-natal considerando a assistência nutricional e identificamos os fatores associados. O estudo transversal, parte do Estudo de Coorte Maternar, foi realizado em 2018 e 2019 no Sul do Brasil. As mulheres foram entrevistadas durante a internação no pós-parto imediato, e os dados foram coletados do cartão de pré-natal. A adequação do pré-natal e da assistência nutricional foram avaliadas de acordo com os critérios do Ministério da Saúde. Dois modelos de desfechos foram construidos. O Desfecho 1 consistia em cobertura minima (inicio precoce do pré-natal e número mínimo de consultas) e exames, e o Desfecho 2, com cobertura minima e exames, acrescidos de assistência nutricional. Foi utilizada a regressão de Poisson para estimar as razões de prevalência. Foram analisadas 802 mulheres, e identificamos 57\% de adequação do Desfecho 1. A gravidez não planejada $(R P=0,76$; IC95\% 0,68-0,86), paridade $(R P=$ 0,88; IC95\%: 0,83-0,94) e pré-natal fora da capital do Estado do Rio Grande do Sul $(R P=0,80$; IC95\%: 0,69-0,92) estiveram associados a menores frequências de pré-natal adequado. O Desfecho 2 foi considerado adequado em 10,2\% das mulheres. $O$ acompanhamento por diferentes profissionais durante o pré-natal esteve associado a menor adequação ( $R P=0,49$; IC95\%: 0,28-0,86). As mulheres com gravidez de alto risco tiveram maior frequência de adequação no Desfecho $1(R P=1,21$; IC95\%: 1,07-1,37) e no Desfecho $2(R P=1,75$; IC95\%: 1,16-2,64). A adequação geral foi considerada baixa para ambos os desfechos. Havia falta de assistência nutricional durante o atendimento pré-natal. Os preditores de adequação do pré-natal incluíam planejamento da gravidez, paridade menor, pré-natal na capital, acompanhamento pelo mesmo profissional e gestação de alto risco.

Cuidado Pré-Natal; Qualidade da Assistência à Saúde; Avaliação Nutricional; Serviços de Saúde Materna; Fenômenos Fisiológicos da Nutrição Pré-Natal

\section{Resumen}

Verificamos la prevalencia de la adecuación del cuidado prenatal, considerando factores relacionados con la asistencia nutricional, así como sus factores asociados. Se trata de un estudio trasversal, que parte del Estudio de Cohorte Maternar, realizada entre 2018-2019 en el sur de Brasil. Las mujeres fueron entrevistadas durante su hospitalización en un período inmediato al postparto $y$ los datos se recogieron de la cartilla prenatal. La adecuación prenatal y nutricional fue evaluada según los criterios del Ministerio de Salud. Se construyeron dos modelos de resultados. El Resultado 1 consistió en una mínima cobertura (inicio temprano prenatal y mínimo número de visitas) y exámenes, y el Resultado 2 tuvo una mínima cobertura, exámenes y asistencia nutricional. La regresión de Poisson se usó para estimar las ratios de prevalencia. Se analizaron a 802 mujeres, e identificamos un $57 \%$ de adecuación al Resultado 1. Embarazo no planeado $(R P=0,76$; IC95\%: 0,68-0,86), paridad ( $R P=0,88$; IC95\%: 0,83-0,94) $y$ cuidado prenatal fuera de la capital del estado de Rio Grande do Sul (RP = 0,80; IC95\%: 0,69-0,92) estuvieron asociados con frecuencias de educación más bajas durante el período prenatal. El Resultado 2 fue considerado adecuado para un 10,2\% de las mujeres. El seguimiento realizado por parte de diferentes profesionales durante el cuidado prenatal estuvo asociado con una adecuación más baja $(R P=0,49$; IC95\%: 0,28-0,86). Las mujeres con embarazos de alto riesgo tuvieron una frecuencia más alta de adecuación en el Resultado $1(R P=$ 1,21; IC95\%: 1,07-1,37) y en el Resultado $2(R P=$ 1,75; IC95\%: 1,16-2,64). La adecuación general fue considerada baja en ambos resultados. Hubo una falta de asistencia nutricional durante el cuidado prenatal. Características tales como: planificación de los embarazos, paridad más baja, cuidado prenatal en la capital, seguimiento por el mismo profesional y embarazo de alto riesgo fueron predictores para la idoneidad del cuidado prenatal.

Atención Prenatal; Calidad de la Atención de Salud; Evaluación Nutricional; Servicios de Salud Materna; Fenómenos Fisiológicos de la Nutrición Prenatal
Submitted on 18/May/2020

Final version resubmitted on 22/Sep/2020

Approved on 09/Oct/2020 